\title{
MARKET IMPERFECTIONS, SOCIAL COSTS OF STRIP MINING, AND POLICY ALTERNATIVES
}

\author{
Robert A. Bohm* James H. Lord*and David A. Patterson**
}

\section{INTRODUCTION}

All but the most hardened defenders of the coal and utility interests must admit that the visual and ecological impact of an unreclaimed stripped area is unfavorable. For those who care to look more deeply, the re are the thousands of miles of acid or otherwise damaged streams and a myriad of resulting damages and treatment costs. There are in excess of one million acres of land disturbed by strip mining, with only a fraction significantly reclaimed. ${ }^{2}$ There are mining counties in Kentucky, West Virginia and elsewhere that simultaneously produce thousands of tons of coal worthmillions of dollars while yielding infant mortality and other human welfare plights that we would expect to find in an underdeveloped country -- not in the U.S.A. The sum total of these impacts, and what they really mean to the human welfare of those who must live in these areas, is a situation which has led some observers to call for the abolition of strip mining, and the reallocation of resources to more deep mining.

Yet deepmining has its costs too. Most of the acid mine drainage originates in deepmines. Soil subsidance and burning is a deep-mine problem. ${ }^{4}$ And worst of all, the human damage of deep mining, as presently carried out, must outweigh any other consideration. In spite of the Mine Safety Act of 1969, figures released by the Bureau of Mines show only a slight decrease in mine accidents. 5 The full extent of black lung among deep miners is just beginning to be realized as state laws and medical examiners officiallyacknowledge the existance of a disease which has accounted for, or contributed to, crippling disability and early death for thousands of coal miners. 6 Thus deep mining is hardly presentable as an attractive alternative to stripping.

Yet, on the other hand, one must have some grasp for the economic importance of coal, or rather, for its major end product, electricity. 7 At the recent Governor's Conference on Meeting Tomorrow's Energy Needs (Chevy Chase, Maryland, September 23-24, 1971) many of the well known perceptions and facts pertaining to this nation's current and future energy requirements and the concomitant environmental problems were reiterated. Among the many prognostications and available options proferred as solutions to the impending crisis was the suggestion that the market be allowed to find its own balance. By this, we presume, the protagonists of such a strategy were reminding us whether we be economists or chemists, friend of "Big Coal" or foe -- that the market mechanism, while not impervious to breakdowns, is capable of handling its own "domestic" problems thank you, and any outside assistance which might be necessary will be solicited --all in good time. It is the considered opinion of the author's of this paper that the re is lacking in this approach a realistic appraisal of the effectiveness of the market mechanism in the case of Appalachian strip-mining.

*Department of Finance, The University of Tennessee.

***Tennessee Valley Authority, on leave from the Department of Economics, The University of Tennessee. 
We would never quarrel with the overriding concern of the participants at the conference, that concern being for the strained resources situation and the financial and technological difficulties in meeting energy demands. However, the prevailing attitude of the power sector seems to be to put highest priority on meeting the future demands for energy and then, if the public is willing, to meet the considerable additional costs of dimishing environmental spillovers. But this attitude reflects a basicmisunderstanding of the economics of the issue, i. e., of the role of price in determining the quantity of energy used. Since society has neverbeen given the chance to vote on the issue in the market place -- more cars, air conditioners, etc. vs. cleaner air and water - - the power producers and others should not project the current trend in energy demands into future estimates of energy requirements without due recognition of probable changes in quantity demanded, and perhaps changes in the price elasticity of demand, when and if the social costs of producing energy are reflected in market prices. Sometimes it seems that the power people get their projections of energy demand from atop Mt. Siani. We would hasten to intercept them and point out that the demand for power is a derived demand. If consumer's point to a new basket of goods and services - - namely, one with fewer hair dryers and cleaner streams in Appalachia - - there is no energy crisis implied by that act per se, and industry should respond by producing the indicated bill of goods. Moreover, the change in emphasis could be accomplished with no dimunition in our "currentper capita consumption of consumables" since what we are going to reallocate from hairdryers to making cleaner streams are the additional resources which will become available to society over and above what will be necessary (given productivity increases) to provide us, each and every one, with a hairdryer. We just won't each have two hairdryers, but rather one hairdryer and clean streams. Let us forever lay to rest the notion that an impending power shortage plays a role in the feasibility of removing envi ronmental spillovers of producing that power. In fact, removing them might alleviate the future power problems.

What is disconcerting in the matter of resource allocation is the failure of the market mechanism to signal producers to supply the socially correct bill of goods in the optimal proportions, and this concern brings up the whole complex problem of externalities i.e., spillover effects, and how to deal with them. 8

\section{EXTERNALITIES AND MARKET FAILURES}

In his well-known treatment of the subject, Francis Bator categorized externalities according to the rationale of why the market fails under certain conditions. 9 His definition of an externality is a situation where some Paretian costs and benefits remain external to decentralized cost-revenue calculations. 10 Loosely translated, externalities are direct, non-market interactions of a producer-producer, consumer-consumer, or producer-consumer type that affect the physical outputs that producers get from their inputs or the satisfaction that individuals get from consumption. These effects are not reflected in prices, therefore they go unnoticed in a market system which is characterized by the decentralized decision making of business firms and households.

\section{The Ownership Externality}

In Bator's classification of externalities the re is the ownership externality, characterized by situations whereproducers a re unable to physically exclude users (beneficiaries), or to control the rationing of their product among them, an examplebeing J. E. Meade's "apple blossom and honey product- 
ion" case. 11 In Meade's classic example the owner of an apple orchard is greatly benefited by his neighbor's activity of keeping bees. The bees crosspollenate the apple blossoms, thus rendering a valuable service to the orchard owner. The latter would realize an increased yield from his orchard if only he could persuade his neighbor to purchase more hives, but the beekeeper is not led to behave in a manner whichwould maximize their joint welfare because he is unable to physically appropriate the benefit that his activity confers on the orchard. The distinguishing characteristic of this case is that difficulties reside in institutional arrangements. The valuable service is rationable and finely divisible and there are no difficulties with "total conditions", i.e., at the bliss-configuration every activity would pay for if elf. ${ }^{12}$ If payment for all of the benefits were only enforceable, then the service in question would be produced in the right amount and would be rationed efficiently. The problem is due exclusively to the difficulty of keeping accounts on recipients of the benefits; the exclusion principle of economics is here inoperative and the market fails because of a lack of proper incentive.

\section{The Public Good Externality}

Another type of externality described by Bator is the public good externality. As analyzed by Paul Samuelson it exists where each man's consumption of a good is related to the total output of that good (or service) rather than as a part of a summation -- as in the case of private goods. 13 Often referred to as collective goods, a public good once supplied to one consumer is supplied to all others at zero marginal cost. 14 Moreover, one individual's consumption of the public good does not decrease the amount of the total available for another person's consumption, and this leads to a special problem in pricing public goods because consumers will not reveal their true preferences. Each individual will understate his preference for a public good, expressed by his reluctance to pay a full-value price, because he knows that if others will reveal their true preferences and pay full-value prices he will enjoy equal benefits and payless than otherswill pay. This situation is different from that of the ownership externality where one man's consumption of the external benefits (which indeed are not feasibly appropriable) reduces the quantity of these benefits which can be consumed by others. 15 Certainly national defense is a public good that closely conforms to the above definitions.

\section{Externalities, The Coal Industry and Legal Conditions}

Environmental spillovers usually embody both the ownership and public good externalities. For instance, acidmine drainage once eliminated for one person is eliminated for all others at no additional cost, and if it is eliminated for one person it is necessarily eliminated for everyone. Therefore, the strip miner is not lead to strip coal in an environmentally compatible way since consumers will not reveal their true preferences for a clean natural environment and pay full-value prices. The exclusion principle is inoperative. Moreover, one person's pleasure from viewing a mountain stream in a pristine state does not diminish the esthetic enjoyment available for others, and any price charged for looking will cause people to underpurchase "viewing" since there is no need to ration it. Thus we can conclude that eliminating acid mine drainage (thus restoring Appalachia's waterways) has public good characteristics, but it alsogives rise to an ownership externality. For example, operators will not strip-mine coal in an environmentally compatible way because the benefits of doing so would accrue to others, and there is no market arrangement, nor practical private institutional device for charging beneficaries. How could mining operators appropriate the benefits to a farmer whose land borders a stream? Clean water is a divisible good and its use can be rationed, but how could users along a waterway be charged for their consumption? 
Viewing the environmental spillover in the above manner clearly shows how the market has failed to provide a good which presumeably is in great demand, and this failure has lead to the current situation, i. e., a situation where laws have been tolerant of pollution and the courts have treated property rights to the environment on a first-come, first-served basis. But the ownership and public good externalities are noless evident when one considers the proposition of reversing the above situation, making the laws on pollution rigorous, with property rights to the natural environment clearly vested in public ownership. If mining companies are required by law to reduce the problem and bear the costs, it is noless important to determine the optimal degree of abatement than in the historical case. Either way it is society's resources which are the stakes, the resources used to prevent acid mine drainage cannot be used to manufacture hairdryers. In this case, however, the public good externality causes each individual to overstate his true preference for clean streams in an effort to maximize his compensation, and this fact may lead a responsive public authority to envoke a much too rigorous set of pollution control laws. The result could be anoverinvestment of society's resources in pollution control laws. The ownership externality in this case is manifest in the fact that the pollution-controlauthority cannot ascertain to what extent each offender is responsible for the total damages. How could the authority keep accounts on damages to each party and how could it establish how much each strip mine was responsible.

\section{ALTERNATIVE POLICY RESPONSES TO MARKET FAILURE}

Failure of the market mechanism to achieve the socially optimal allocation of resources brings up the question of how to correct for its deficiency. To develop the answer let us begin by calling $X$ a group of strip mining interests which impose an externaldiseconomy, and $Y$ the public residing in Appalachia. ${ }^{16}$ How much Y suffers depends not only on the scale of $\mathrm{X}^{\prime} \mathrm{s}$ activity, but also upon the nature of the activity and upon $\mathrm{Y}^{\prime} \mathrm{s}$ reaction to it. If the activity in question is strip mining land, $Y^{\prime}$ 's loss will depend not only on the number of acres left unrestored but also on the condition of the disturbed land and the economic cost to $Y$ of overcoming the effects of acid mine drainage, siltation, land slides, etc. To determine the proper commitment of society's resources for alleviating the problem requires an investigation into the nature and cost of alternative activities open to $\mathrm{X}$ and devices by which the public can reduce the impact of each activity. 17 The optimum scale and nature of restoring the land and the proper adjustment to it by $Y$ is that outcome which maximizes the algebraic sum of $Y^{\prime}$ s gain to $Y^{\prime} s$ loss.

The diagram in Figure 1 shows the relevant variables. The assumption here is that two types of land restoration a re available to $\mathrm{X}$ - - Activity I, no effort and Activity II, thorough reclamation. Even in the event of a complete reclamation effort, however, some damage to Y occurs. For example, reclaimed land is ugly and erosion prone until reforestation takes effect. The scale of each activity and the losses sustained by $\mathrm{Y}$ are measured as continuous variables. The area under $X^{\prime} s$ curves reflects the gain to $X$ of leaving strip-mined land in two alternative conditions while the area under $\mathrm{Y}^{\prime} \mathrm{s}$ curves gives the total loss to $\mathrm{Y}$, in each case, after he has made the best possible adjustment to the damages; thus it measures the direct loss to $Y$ after the adjustment plus the cost to $\mathrm{Y}$ of making the adjustment.

If $\mathrm{X}$ is unhampered by any restrictions he would choose activity I (no reclamation) at a scale of ON. From the social point of view OM is better than ON. However, the socially optimal outcome is for $\mathrm{X}$ to engage in full restoration, Activity II, at a scale of OT since a rea OZW is greater than area JKL. With the Appalachian public in a weak position but able to bargain with $X$, it should subsidize the proper restoration of land by paying up to (OJLN + 
FIGURE 1
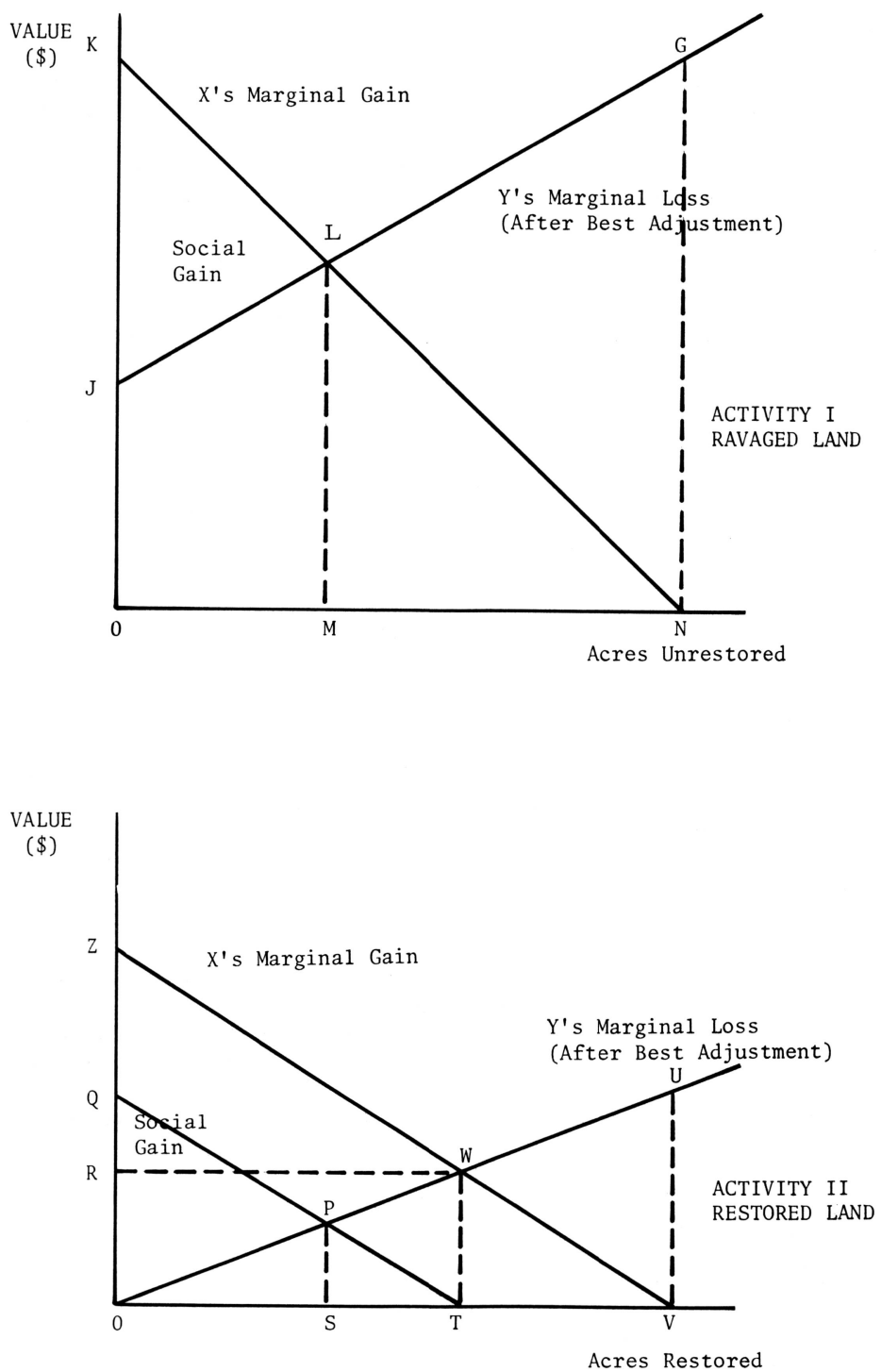

Adapted from Ralph Turvey, "On Divergences Between Private and Social Cost," Economica, (1963), p. 311. 
LGN - OWT) to induce X to Activity II at a scale OT. Certainly Xwill accept as little as (JKL + OJLN-OZW-OWT) to cooperate. The difference between the maximum bribe offered and the minimum acceptable payment is (LGN $\mathrm{JKL}+\mathrm{OZW}$ ) which is the maximum social gain to be shared between them.18 Changing the legal environment so that $\mathrm{X}$ is liable to $\mathrm{Y}$ for external damages would induce mining companies to move to activity II at a scale OT (the optimum allocation) pay OWT to Y and retain a net gain of OZW. Thus the result is the same as when there is no liability, although the distribution of the gain is very different; as demonstrated earlier Y would pay up to (OJLN + LGN - OWT) to induce X to move to activity II at a scale OT. It follows that, if bargaining can take place, questions of property rights to the use of the natural environment in Appalachia are a matter of income and wealth distribution and not a matter of efficient use of society's resources. Realistically, of course, state intervention is necessary because the Appalachian public is too large a group formembers to get together for direct bargaining with the coal industry. However, we hasten to point out that government intervention can be a very complex and costly undertaking where the goal is to achieve the optimal resource allocation, which is Activity II at a scale of OT.

The problems faced by the state authority are (1) to list and evaluate all of the alternative activities available to $\mathrm{X}$ and examine their effects on $\mathrm{Y}$; (2) to determine adjustments available to $Y$ for reducing the direct loss suffered and the costs of these adjustments; and (3) to determine what measures are necessary to move the market toward the optimum and the costs of determing and enforcing the change. Moreover, before the state will move to take action, it should (1) be sure that the gains from resource allocation outweigh the costs of affecting and maintaining the change and (2) be sure that any income redistribution can be justified.

In the examples just discussed, the nature of the activity as well as the scale of the activity are variable so it is necessary to control both. No amount of tax per acre of strip-mined landwould induce coal interests to move from activity I to activity II, because X's net marginal gain after paying the tax would be greater with activity I than II. ${ }^{19}$ It would be necessa ry to enforce the practice of activity II (full land reclamation) and then impose a tax of WT per acre of restored land to move $X$ to scale OT.

What could be true is that the costs of achieving this optimum resource allocation outweigh the gains, the latter given by (LGN - JKL + OZW) and this is an empirical question. The costs of restoring the land, of course, are paid for by the strip-mining interests - - reflected in Figurel by the shift downward of $\mathrm{X}^{\prime} \mathrm{s}$ marginal gain, (from Activity I to Activity II). There are two assumptions here: (1) that none of these costs can be passed on through higher prices for strip-mined coal because deep-mined coal is a nearly perfect substitute, and (2) the number of strip mining firms remains unchanged. Certainly there would be considerable costs of affecting and enforcing Activity II as well as the tax WT. Total tax receipts would be equal to the a rea ORWT. The collection of this tax would give rise to $X^{\prime}$ s net marginal gain curve which is the line QT. If $X$ then moves to output OT (optimal for society and $\mathrm{X}$ ) it will pay $\mathrm{X}$ to induce him to move to position $\mathrm{S}$ (which is suboptimal) as it is this position which maximizes $X$ and $Y^{\prime} s$ joint net gain. 20 Even in this case Y still sustains a diseconomy equal to OPS. This problem of a sub-optimal outcome as well as the problem of Y sustaining a diseconomy could be taken care of by using the tax revenue ORWT to fully compensate Y for the diseconomy (OWT) sustained in the socially optimal circumstance. This leaves a residual tax revenue equal to ORW to contribute to the administration and enforcement costs of both the reclamation standards and the $\operatorname{tax}$ WT. 
It may well be that the administration and enforcement costs a re greater than LGW - JKL + OZW, the gains from the optimal solution; moreover, it may be that strip-mining cannot operate profitably under the reclamation standards and the tax WT (assuming no increase in coal price). If either is true in the Appalachian strip-mining situation, then a strong case can be made for disallowing all strip-mining rather than permit ON acres to remain ravaged (since JKL is less than LGN). However, if the administrative costs of enforcing a standard reclamation policy (with no tax, WT) are less than $(\mathrm{OZW}+\mathrm{LGN}$ - JKL - WUV), a nother solution would be to continue strip mining but envoke the flat requirement that all acres be fully restored as in Activity II. This solution may be referred to as the "standards"solution and usually takes the form of a severe penalty if land is not restored in a standard manner. ${ }^{21}$ Thus, strip-mine operators would choose Activity II at a scale OV rather than endure the penalty and would avoidmine sites that are unrecoverable.

Within the context of the partial equilibrium analysis presented here, the "standards" solution is no more than a second best solution from the point of view of economic efficiency. However, if may well be a more feasible solution. To achieve the socially optimal solution would require the as sembly of enormous amounts of information to determine WT as well as to continually readjust the tax anytime $X$ 's marginal gain curve shifted (which would happen if $X$ passed on to consumers any of the costs of restoration, any of the tax, or if firms were to drop out of the industry) or Y's marginal loss curve shifted.

It should be noted that for a "tax" measure alone to achieve the optimum without the standards policy, charges would have to belevied in accordance with the quantity of damages inflicted. But this system would be almost impossible to administer since it would require a constant monitoring of damages. As a consequence the usual suggestion is a flat rate charge per ton of strip-mined coal (e.q. a severance tax). ${ }^{22}$ This is certainly "a less than second best solution" since minor offenders under a flat-rate system (say partial restoration) would subsidize the major violators (say no restoration) if both were paying the same taxper unit of output. Furthermore, as pointed out earlier, the same output tax levied on major and miner offenders would do nothing to encourage strip miners to engage in better restoration techniques. On the basis of the preceding analysis, it is our intuitive judgment that the "standards" solution is the preferred policy alternative.

\section{THE BENEFITS AND COSTS OF ABATEMENT}

Irrespective of the final choice between an optimal solution or "second best" solution, the first decision that must be made is whether a shift from activity I to activity II is indeed economically warranted. Such a shift requires that the value of the external costs which a re controlled or eliminated, (i. e., the net benefits of any environmental protection policy) equal or exceed the cost of effecting and maintaining the change. Again we should point out that net benefits are heredefined as the benefits to the public of removing the spillovers over and above the negative effects inflicited on the mining interests. In the graphical analysis presented above this was assumed to be the case, (i.e., area OZW is greaterthan area JKL). However, in the real world, it is not entirely clear that such a case has been firmly established. Rather, the approach of the environmentalists has been to first make a value judgement that pollution is "bad" from which follows the logical conclusion that "something must be done".

Any environmental policy aimed at the elimination or reduction of the external environmental costs of coal production must enumerate, in value terms, the benefits and costs to be achieved. If this is not done, society has 
no way of knowing if it is better off after the spillovers have been eliminated than it was before. In otherwords, it is possible that the reallocation of society's resources towards cleaner streams is an inferior position in terms of the overall level of welfare attained.

\section{Benefits Estimation}

On the benefits side, a considerable literature is rapidly appearing which identifies a large humber of detrimental environmental effects which result from coal mining and coal use. The number of un reclaimed stripped acres $(1,024,000$ in 1970), the number of tons of mine acid produced per day due to strip mining $(1,500)$, and the number of acres of ponds and lakes adversely affected by slit and acid $(145,146)$, etc. are rapidly becoming familiar figures. ${ }^{23}$ We hasten to point out, however, that only in a few instances have the value of these spillovers been estimated. Such a "costing out" of both benefits and costs of environmental action is perhaps the most important task at hand today in the area of environmental research.

Some estimates of the value of benefits, of course, do exist. For example, the Department of the Interior estimates that strip mining destroys 35 million dollars of outdoor recreation resources annually. 24 The enormous potential benefits to be gained from control of environmental spillovers of coal, however, are best illustrated by reference to external costs imposed on humans by current methods of coalusage. A recentestimate based on the use of coal to produce electricity indicates that accidients in mining and processing of all coal lead to the death of one man per yerper $1,000 \mathrm{MWE}$ produced. 25 To the individual in question, of course, the value of his life is infinite. However, a finite estimate of the market value of his future earning power can be derived. If we as sume that the fatality in question has 20 working years left and his average wage during that future period is between $\$ 8,000$ and $\$ 10,000$ a year than a direct economic loss to society of $\$ 160,000$ to 200,000 (undiscounted) ensues over the period.

Lung disease, excluding lung cancer, from coal mining and processing may result in up to 15 premature deaths per year per $1,000 \mathrm{MWE}{ }^{26}$ The number of deaths is probably indicative of a much larger number of sufferers of cronic black lung disease and other respiratory ailments. In this case, the earning power of the afflicted is greatly reduced if not zero. In addition, society bears the further cost of medical care and compensation.

\section{The Costs of Abatement}

The costs of abating the ill effects of coal related environmental spillovers are seldom discussed. These costs include the direct costs of abatement plus information costs and enforcement costs. All three are important because they involve resources which have alternative uses; they are a measure of the benefits society forgoes when it decides to engage in abatement.

In choosing the actual abatement policy, information and enforcement costs are indeed crucial variables. Recall in part III above, four acceptable policy options were discussed as alternative ways of dealing with environmental spillovers from strip mining. Thesealternatives are: (1) do nothing; (2) a tax plus standards solution (efficiency optimum); (3) establish standards (second best); or (4) outlaw the activity entirely. The information and enforcement costs of doing nothing are, of course, zero. If this option is chosen, society continues to absorb the external costs of coal production which are presumably less than the costs of doing anything. Likewise, information and enforcement costs of "outlawing" the activity are probably 
slight. In this case, however, a major mining process, which may well be the industry's most economical technique, would be outlawed on non-economic grounds.

The information and enforcement costs of effecting the standards plus tax solution are probably prohibitive. Not only must a basic benefit-cost study be undertaken but marginal cost and benefit schedules must be derived from the data and constantly updated, since they are necessary for proper enforcement. As mentioned earlier, a uniform "output" tax is feasible but sub-optimal in terms of its effect on pollution and equity. The "standard" solution requires only the basic benefit-cost study perhaps periodically updated. Information costs of the "standards" solution may be high but certainly not as high as those of the standards plus tax solution. Moreover, the enforcement costs of the "standards" solution would be' considerably less than those of the standards plustaxsolution-- since the detection of any violation can be accomplished visually. The costs entailed in complete wage and price administration World War II style, as opposed to the 1971 wage and price freeze are probably indicative of the difference in magnitude of the information and enforcement costs of the standards plus tax solution versus the standards solution.

\section{INCOME REDISTRIBUTION EFFECTS}

Policies to control pollution and other spillovers of coal production and consumption are likely to have side effects of their own. These effects will largely be transfer effects or what a re known in economics as pecuniary external effects. From the point of view of economic efficiency they are irrelevant. From the point of view of the distribution of income and wealth in society, however, pecuniary external effects may be extremely important.

Pecuniary external effects are nothing more than the market reacting to changes in demand or to a change in institutional arrangements. At any point in time a set of these effects are embedded in the economic system. As a result of the existing effects some individuals have gained and some have lost over time. By changing institutional arrangements, for example, a new set of pecuniary external effects is generated which create a new set of gainers and losers. As noted above, society must make a judgement regarding the desirability of any change, presumably through the political process.

Income redistribution effects a re probably of greatest concern when the suggested policy is to completely outlaw some activity. For example, consider the possible consequences of outlawing all strip mining of coal. The initial effect would be unemployment for all strip miners and an increase in demand for deep mined coal. Since the Mine Safety Act of 1969 undoubtedly reduced the elasticity of supply of deep-mined coal, its price would rise appreciably resulting in windfall profits for the owners (somewhat counteracting the windfall profits earned by strip mine owners as a result of the Mine Safety Act) since wages typically react slowly in such cases. The high price of deep-mined coal will result in attempts at substitution in production by heavy coal users. To the extent that production functions cannot be altered instantaneously, however, extensive substitution by consumers will occur away from goods with a heavy coal component.

The unemployed strip miners will not completely forsake their current location for at least as long as required for the Supreme Court to decide the constitutionality of outlawing strip mining. In the interim, they will be unemployed and drawing unemployment compensation. In Appalachia along the re were 11,697 strip miners in 1967. 27 If they draw an average of 52.15 dollars 
per week for 24 weeks ( 6 months), the cost will be $\$ 14,639,974$ as suming no reemployment during the period and the collection of full benefits. 28 These payments amount to an income redistribution from the general public to a special group.

Consider further the plight of many Appalachian communities for which strip mining is the major source of basic employment and income. Successful outlawing of strip mining will undoubtedly doom them as viable economic units, poor as they may now be. On the other hand, communities that depend on deep mining will benefit. It is perhaps here that potential contradictions in public policy and the importance of distribution effects in environmental programs may be seen. While irrelevant in terms of national economic efficiency, pecuniary external effects a re quite real and may result in severe hardships at specific locations. Public sector concern for the income distribution problem has recently manifestitself in the formation of such agencies as the Appalachian Regional Commission, the Economic Development Administration, etc. These agencies have devoted considerable resources to the economic development of depressed areas. In fact, a popular technique employed to foster economic development has been the use of pecuniary external effects of such public investments as highways in Appalachia. To ignore the potentially contradictory distribution effects of environmental programs certainly seems criminally naive.

\section{POLICY RECOMMENDATION}

As already indicated, the re are four basic policyoptions. The do-nothing alternative seems indefensible, if not already eliminated from consideration by the nation's environmental consciousness. Similarly, the complete prohibition of stripmining is not a valid proposal if techniques of reclaimation can be devised which are environmentally compatible.

The tax solution was describedas having two forms. One is a flat rate tax per ton or per dollar of sales. This has the obvious disadvantage of being unrelated to the true cost of the polluting activity, except perhaps on an average basis. The optimal tax would be in conjunction with a standard reclamation policy and would overcome this difficiency but require extensive cost analysis as well as post-mining inspection of each site. Of course, a flat severance tax may be proposed and justified simply for its income producing, and in this case income redistributional effects. This would be, in effect, a tax on the users of coal paid to residents of coal producing states. Such a tax would then merely join a long list of taxes with redistributional effects but with no predictable effect on strip mining pollution.

The final alternative is the "standard" solution. This is the option already adopted in most states. 29 However, standards have been so low and enforcement provisions so weak that benefits have been nonexistent. For this reason, standards have earned an undeserved bad name.

Standards can be set to meet whatever goal society decides is economically and environmentally justified. The Tennessee Valley Authority is currently experimenting with new mining techniques that would leave the terrain closer to its original position than generally believed possible in the past at a cost of less than two dollars per ton or probably about equal to the German cost experience. In any case the effectiveness of standards depends essentially on only one variable; the public will for a sufficiently strong law and effective enforcement.

Assuming that effective standards can be made into law and enforced and considering the cost and benefits of implementing the various control policies, it is our judgement that the standards solution is the preferred policy alternative. 
${ }^{1}$ An earlier version of this paperwas presented at a Symposium on Coal and Public Policy held at the University of Tennessee, Knoxville, October $13-15,1971$.

2 United States Department of the Interior, Surface Mining and Our Environment, 1966, pp. 32-49. Also Appalachian Regional Commission, Acid Mine Drainage in Appalachia, 1969; Marion Edey, "Strip Mining Legislation," No Man Apart (July, 1971) pp. 7-8 and statement of the Honorable Ken Hechler before subcommittee on Mines and Mining, Congressional Record, September 20, 1971, p. E9885.

${ }^{3}$ See the discussion in Mary Jean Bowman and W. Warren Haynes, Resources and People in EastKentucky (Baltimore, Maryland: The Johns Hopkins Press, 1963) esp. pp. 180-242.

${ }^{4}$ See the interesting comments of M. Gordon Walman, Science (Nov. 26, 1971) p. 909. Also Nashville Tennessean (December 3, 1971).

${ }^{5}$ United States Department of the Interior, Bureau of Mines, Mineral Industry Survey, October, 1971.

${ }^{6}$ United Mine Workers of America, Black Lung, 1969.

${ }^{7}$ See for example the data presented in Bituminous Coal Facts 1968, (Washington, D. C. : National Coal Association, 1968).

8 The assumption here, of course, is that the recent clamor about environmental spillovers reflect a true (effective) demand for their removal.

${ }^{9}$ Francis Bator, "The Anatomy of Market Failure", Quarterly Journal of Economics, LXXII, (1958), pp. 351-379.

${ }^{10}$ Ibid.

${ }^{11}$ J. E. Meade, "ExternalEconomies and Diseconomies in a Competitive Situation". Economic Journal, LXII, (1952), pp. 54-67.

${ }^{12}$ In equilibrium of production and exchange the re is a set of shadowprices implied by the marginal-rate-of-substitution equalities which would efficiently ration the bill of goods; moreover, this set of prices will signal the sociallycorrect bill of goods and will lead to their optimal production. This conclusion is predicated on the assumption that the re are no indivisibilities and/or increasing returns in production. The consequence of indivisibility or increasing returns (in inputs, outputs, or processes) is to render the set of feasible points in production (input-output space) nonconvex. Nonconvexity disallows dualty and is referred to by Bator as a technical externality. For a further discussion see Bator, op. cit., pp. 63-69.

${ }^{13}$ P.A. Samuelson, "The Pure Theory of Public Expenditures", Review of Economics and Statistics, XXXVI, (1954) pp. 387-89 and P.A. Samuelson, "Diagrammatic Exposition of a Theory of Public Expenditures", Review of Economics and Statistics, XXXII (1955), pp. 350-356.

14Warren Robinson, "Benefits Received Financing in the Federal System", National Tax Journal, XXVII, (1964), p. 242. 
${ }^{15}$ The public good externality exists in what is otherwise a neoclassical world, i.e., preference and production functions are convex throughout. If $y$ is the numeraire, the marginal $y-\cos t$ of $x$ in production, $p_{x}$, is the efficient price for $\mathrm{x}$. If $\mathrm{x}$ is offered for sale at $\mathrm{p}_{\mathrm{x}}$ and consumers adjust their purchases so that their individual marginal rates of substitution are equal to $\mathrm{p}_{\mathrm{x}}$, they will necessarily underconsume $\mathrm{x}$ because additional consumption would not interfere with another person's (who is also paying $\mathrm{p}_{\mathrm{x}}$ and under consuming) consumption. There is no set of prices associated with the bliss point which will sustain the configuration; i. e., a set of prices which would induce competitive producers to produce the optimumbill of goods would be inefficient in allocating that bill of goods. The re are no nonconvexities involved nor would any accounting device, if one were only feasible, solve the problem. See Bator, op. cit., pp. 69-71, and Samuelson, "Diagramatic Exposition of a Theory of Public Expenditure", op. cit., p. 350.

${ }^{16}$ It is important to point out that $X$, the strip mine operator, by externalizing some costs to the environment, is able to (1) earn excessive profits and/or (2) sell coal for "environmentally subsidized" prices. If the latte $r$ is true then $X$ represents the public interest as well as private stripmine ownership interests. Viewed in this way the external costs of stripmining amount to a welfare transfer: a transfer of welfarefrom the relatively few who endure the external costs to the larger public who benefit from subsidized coal prices.

17 The following analysis is based on Ralph Turvey, "On Divergences Between Social Cost and Private Cost", Economica (1963) pp. 309-313.

${ }^{18}$ The realism of this theory is easilymissed by too narrow an understanding of the term "bribe". If one views the theory in the contexts of the current debates raging in several state legislatures and in the Federal Congress, the analog between "bribe" and the political compromise usually necessary to achieve new legislation is more obvious.

${ }^{19} \mathrm{~A}$ severance tax per ton of coal indirectly amounts to a tax per acre.

${ }^{20}$ Clearly a stable solution occurs only at the origin.

21 The most popular proposed penalty is forfeiture of a performance bond if adequate reclamation is not undertaken. Strip-mine bills which include a bonding provision have recently been proposed or enacted in Missouri, Virginia, Alabama, Kentucky, Tennessee, West Virginia and by Senators Baker (R, Tennessee) and Cooper (R, Kentucky) and Senator Aspinall (D, Colorado). See St. Louis Post-Dispatch, April 4, 1971; Bristol Herald Courier, January 7, 1972; Decatur Daily, October 1, 1970; Louisville Courtier Journal, April 4, 1971 and December 14, 1971; Memphis Press-Scimitar,October 12,1971 . The amounts of the bonds proposed varies considerably and in many cases may not be sufficient to force Activity II.

${ }^{22}$ Senator Lee Metcalf (Montana) has proposed a tax of $5 \%$ of sales on all extractive minerals (Congressional Record, November 29, 1971, S1843). Other proposed taxes range as high as $10 \%$. In Germany restoration of stripmined land costs $\$ 1.25$ per ton. Tennessee Valley Authority experience indicates a cost of 15 to 25 cents per ton for reclamation meeting present Tennessee Valley Authority standards (New York Times, December 7, 1971). However, "reclamation" and "restoration" a revastly different, both in terms of visual impact and land-use potential.

${ }^{23}$ Statement of the Honorable Ken Hechler before Subcommittee on Mines and Mining, Congressional Record, September 20, 1971, p. E9885. 
24 Ibid.

${ }^{25}$ Data derived from Chauncy Star, Nuclear Safety, V (1964), p. 325. The shift to strip mine coal since 1964 should have reduced this ratio considerably.

\section{${ }^{26}$ Ibid.}

${ }^{27}$ Appalachia is defined here as the coal mining a reas of Alabama, Kentucky, Maryland, Pennsylvania, Tennessee, Virginia, and West Virginia. Data derived from Bituminious Coal Facts 1968, (Washington, D. C., National Coal Association, 1968), p. 68.

28 This amount is the national ave rage compensation paid between July, 1970 and June 1971. Data derived from Monthly Labor Review, 94, (September, 1971), p. 93.

${ }^{29}$ U.S. Department of the Interior, Study of Strip and Surface Mining in Appalachia, 1966, Appendix II and footnote 21. 